Témoigner Témoigner. Entre histoire et mémoire

Getuigen Revue pluridisciplinaire de la Fondation Auschwitz

$122 \mid 2016$

Révisionisme et négationisme

\title{
Moordcentrum Sobibór: de techniek van de dood ontrafeld
}

Le centre de mise à mort de Sobibór. Le secret de la technique de mise à mort à Sobibór mis à jour.

Johan Puttemans

\section{(2) OpenEdition}

Journals

\section{Édition électronique}

URL : https://journals.openedition.org/temoigner/4094

DOI : $10.4000 /$ temoigner.4094

ISSN : 2506-6390

Éditeur :

Éditions du Centre d'études et de documentation Mémoire d'Auschwitz, Éditions Kimé

Édition imprimée

Date de publication : 2 mai 2016

Pagination : 32-39

ISSN : 2031-4183

Référence électronique

Johan Puttemans, «Moordcentrum Sobibór: de techniek van de dood ontrafeld», Témoigner. Entre histoire et mémoire [Online], 122 | 2016, Online op 30 septembre 2021, geraadpleegd op 08 janvier 2022. URL: http://journals.openedition.org/temoigner/4094 ; DOI: https://doi.org/10.4000/temoigner. 4094

Tous droits réservés 


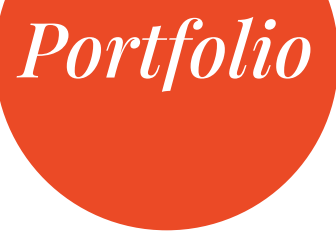

MOORDCENTRUM
SOBIBÓR

\section{De techniek van de dood ontrafeld}

\author{
$\rightarrow$ G.B. = \\ (C) Georges Boschloos - \\ VZW Auschwitz in \\ Gedachtenis / \\ Stichting Auschwitz \\ J.P. = \\ (C) Johan Puttemans - \\ VZW Auschwitz in \\ Gedachtenis / \\ Stichting Auschwitz
}

(1) Bepaald tijdens de geheime conferentie te Wannsee op 20 januari 1942.

Bron:

http://www.deathcamps.org/ reinhard/wannsee/text.html

(2) Naar de term van Patrick Desbois (Porteur de mémoires : sur les traces de la Shoah par balles, Parijs: Michel Lafon, 2007).

(3) De term verwijst naar de uitroeiing van de Joden van het Generaal Gouvernement en het District Białystok.

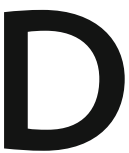

e na de Eerste Wereldoorlog gestichte Tweede Poolse Republiek wordt na de verovering door nazi-Duitsland en de U.S.S.R. verdeeld onder beide dictatoriale staten. Het westen wordt opgenomen door Hitlers Duitsland, en Stalins communistische unie lijft het oosten in. Het centrale gedeelte wordt als bufferstaat tussen de agressieve grootmachten opgetrokken. Tijdens de Tweede Wereldoorlog staat Midden-Polen als Generalgouvernement onder het bewind van nazijurist Hans Frank, en fungeert het als een vazalstaat waarbij de bevelen onmiddellijk van Berlijn afkomstig zijn. Opmerkenswaardig is dat een antisemitische en racistische macht met de verovering en officieuze incorporatie van Midden-Polen niet louter Slavische 'Untermenschen'opnam, maar evenzeer zo'n 2284000 Joden. ${ }^{1}$ Wanneer Hitler in de herfst van 1941 beslist om alle Joden in Europa uit te roeien, vormt de omvangrijke Joodse gemeenschap in de vazalstaat dan ook een vraagstuk op zich.

De Holocaust door kogels $^{2}$, zoals die plaatsvond in de bezette oostelijke gebieden, blijkt onuitvoerbaar in het Generaal-gouvernement. Er worden daarom drie vernietigingscentra opgetrokken. In maart' 42 start Bełżec als eerste centrum van 'Aktion Reinhardt'. ${ }^{3}$ Het netwerk wordt een maand later uitgebreid met de bouw van een tweede centrum, nabij het Poolse dorp Sobibór. Het dichtbeboste en moerasachtige gebied, dat op vijf kilometer van de rivier Bug ligt, markeert de scheiding tussen het Generaal-gouvernement en het Reichskommissiariat Oekraïne. Hier kunnen de nazi's de Joodse bevolking ongemerkt uitroeien.

Om de 'capaciteit' te optimaliseren, vinden uitbreidingswerken plaats in de vernietigingscentra. Eind juli ’ 42 wordt de oude gaskamer van Sobibór vervangen door een nieuw stenen gebouw.SS-Unterscharführer (sergeant) Erwin Lambert voert deze werken uit. Van de lente van 1942 tot de herfst van 1943 zullen tussen 170000 en 250000 Joden onmiddellijk bij aankomst vermoord worden. 


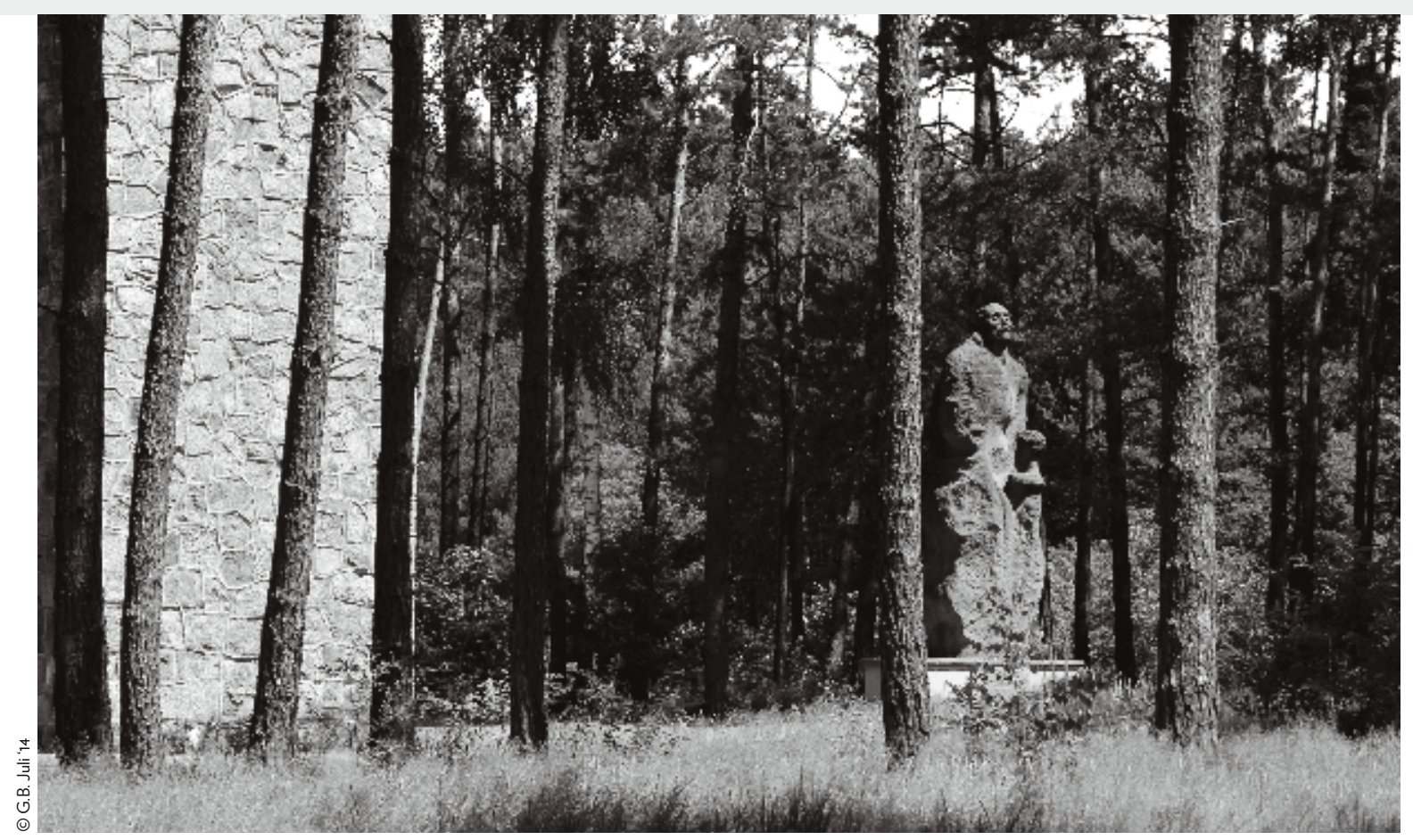

Na de opstand in Sobibór op 14 oktober 1943 zal een vijftigtal van de tweehonderd ontsnapte Joden het overleven. Het zijn Arbeitsjuden, Joodse dwangarbeiders die de goederen van de vergaste Joden moesten sorteren. Eén van hen is de in oktober 2015 overleden Thomas Blatt.

Tijdens de herfst van 1943 worden op bevel van Heinrich Himmler, het hoofd van de SS, de sporen van de genocide uitgewist. Aan de hand van getuigenissen van zowel Joodse overlevenden als gewezen SS-bewakers heeft men toch inzicht kunnen krijgen in de werking van het centrum en is men erin geslaagd enkele grove, en niet altijd eenduidige, schetsen te maken.

In 2000 en 2001 deed de Poolse historicus en archeoloog prof. dr. Andrzej Koła opgravingen in Sobibór. Hoewel hij meerdere massagraven wist te lokaliseren, bleef het moeilijk om een totaalbeeld te krijgen van het vernietigingscentrum. De Israëlische archeo- loog Yoram Haimi, die sinds 2007 samen met zijn Poolse collega Wojchiech Mazurek jaarlijks opgravingen organiseert, deed echter verschillende interessante ontdekkingen. In 2010 vond hij de dubbele omheining, in 2011 kon de 240 meter lange Schlauch (de weg die naar de gaskamers leidde) blootgelegd worden, en in 2013 groeven de collega's objecten op die de slachtoffers toebehoorden. In september 2014 werd een ontdekking gedaan van het grootste belang: de archeologen vonden de bakstenen fundering van de gaskamers. Het ging om vier ruimten en een gang, die zich bevonden in het enige stenen gebouw op de site. Al deze ontdekkingen zullen opgenomen worden in het nieuwe memoriaal. Verwacht wordt, dat het moordcentrum Sobibór in de toekomst nog meer van zijn geheimen zal prijsgeven.

Johan Puttemans

VZW Auschwitz in Gedachtenis /

Stichting Auschwitz
Situatie vóór de archeologische opgravingen.

De kolom in natuursteen symboliseert de gaskamers. Gebouwd in 1965 door de Poolse beeldhouwer Mieczysław Welter. 
$\rightarrow$ Situatie vóór de archeologische opgravingen. Het monument op de voorgrond symboliseert een vrouw met kind die vermoord werden in de gaskamers. Gebouwd in 1965 door de Poolse beeldhouwer Mieczysław Welter. Halverwege de jaren tachtig werd het monument verplaatst.

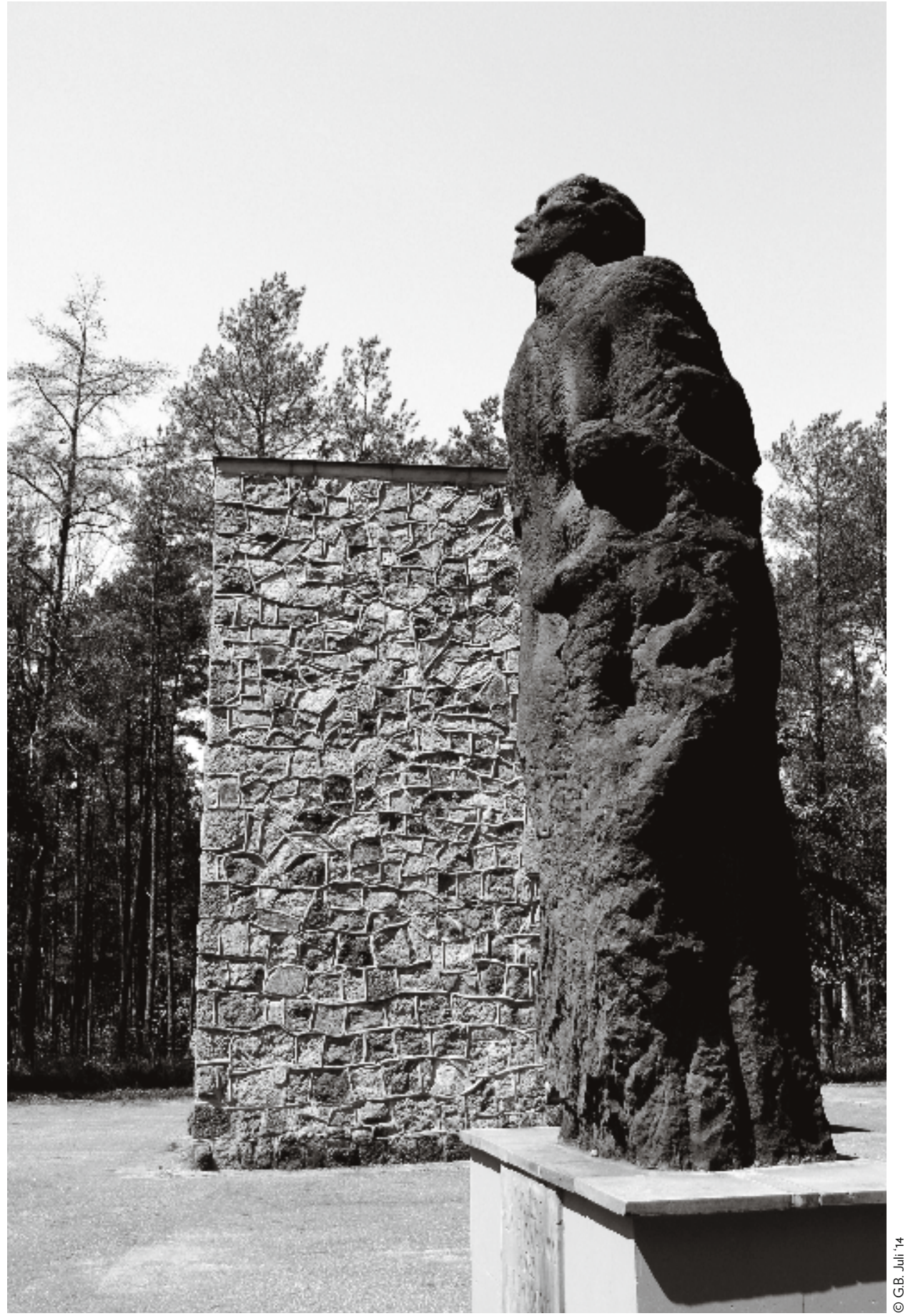



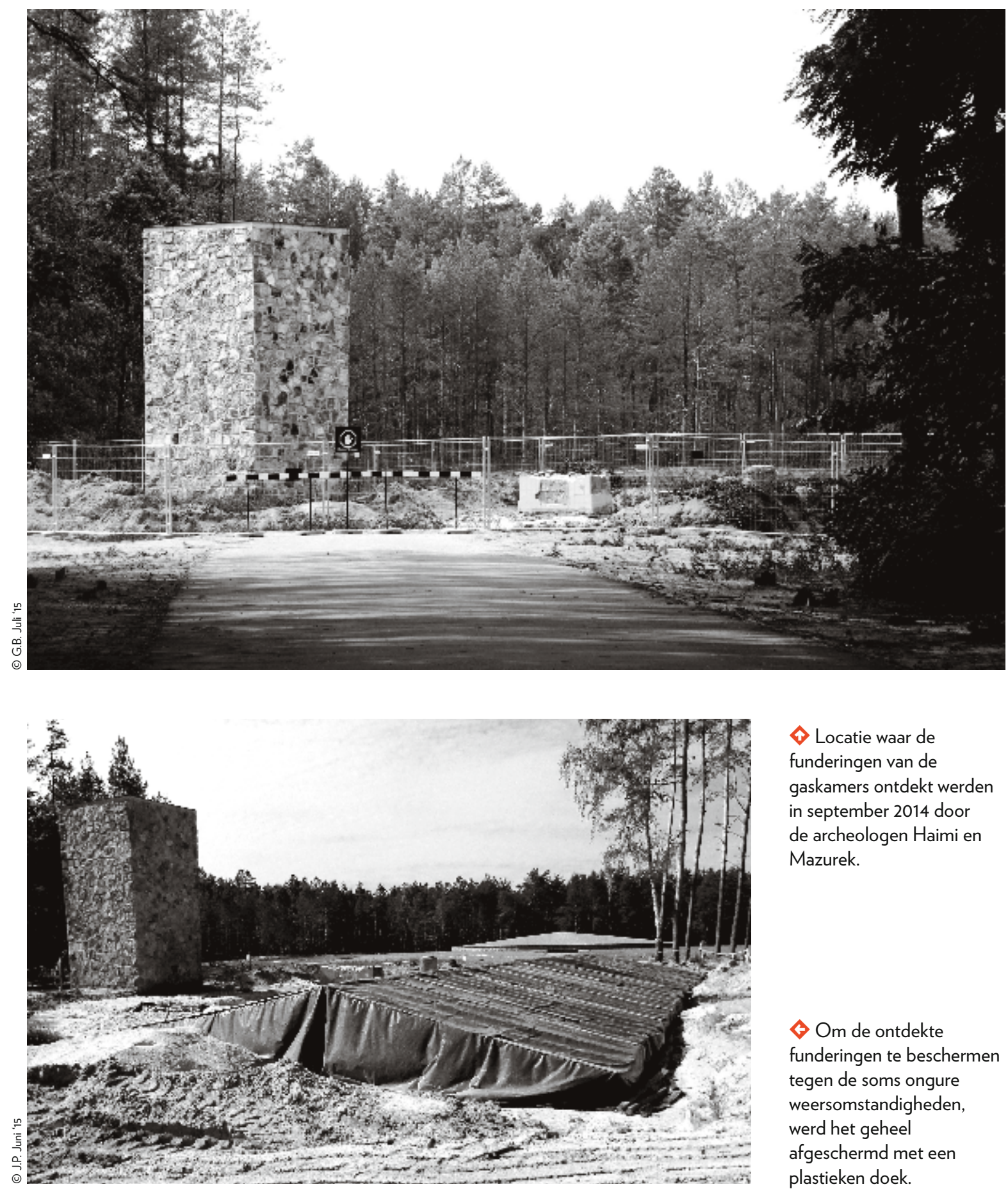

Locatie waar de funderingen van de gaskamers ontdekt werden in september 2014 door de archeologen Haimi en Mazurek.

$\leftrightarrow$ Om de ontdekte funderingen te beschermen tegen de soms ongure weersomstandigheden, werd het geheel afgeschermd met een plastieken doek. 


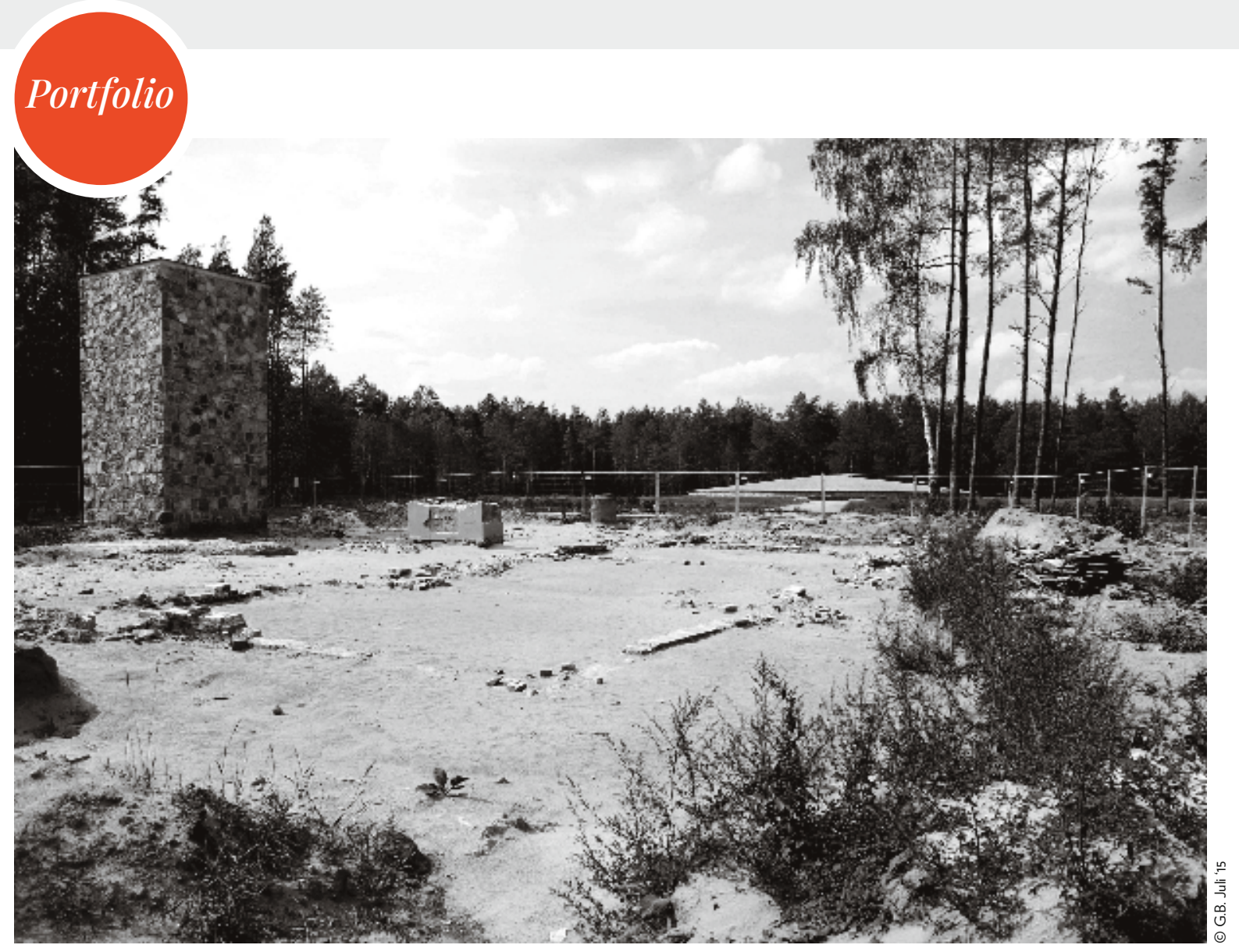

$\checkmark$ Het weggehaalde betonnen wegdek onthult de funderingen van de gaskamers van het moordcentrum te Sobibór.

$\diamond$ De duidelijke herkenbare funderingen van de gaskamers die in de zomer van 1942 gebouwd werden om het moordcapaciteit te verhogen.

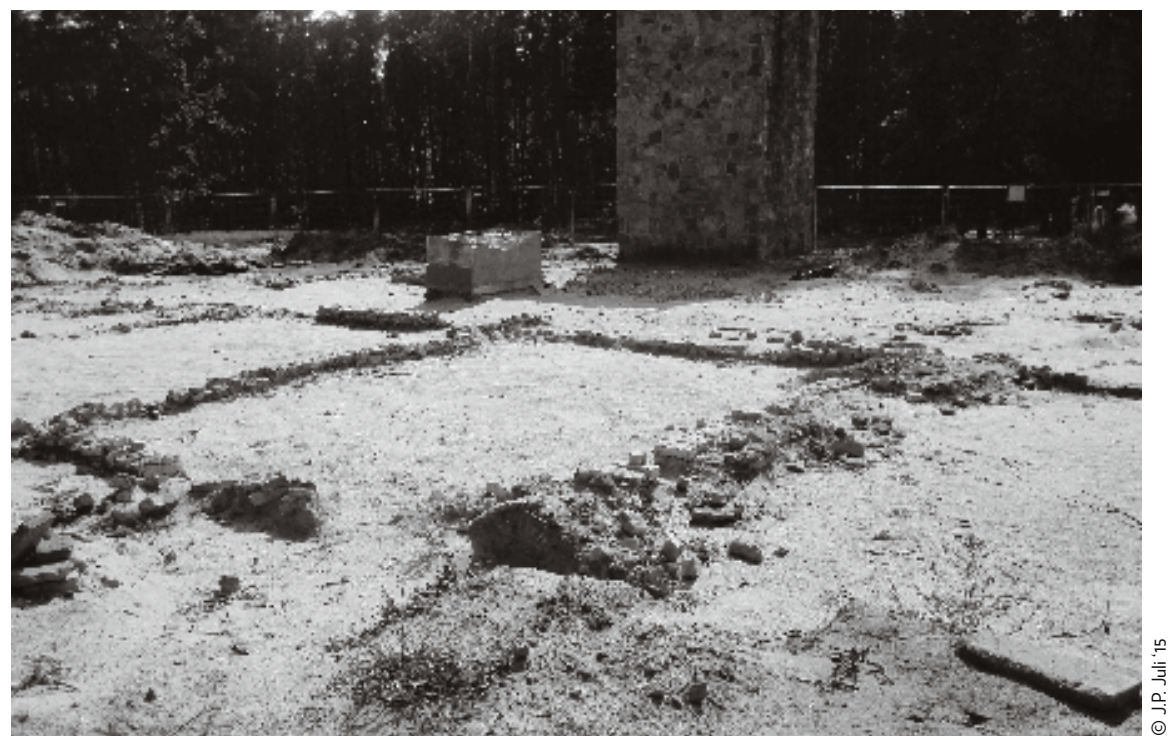



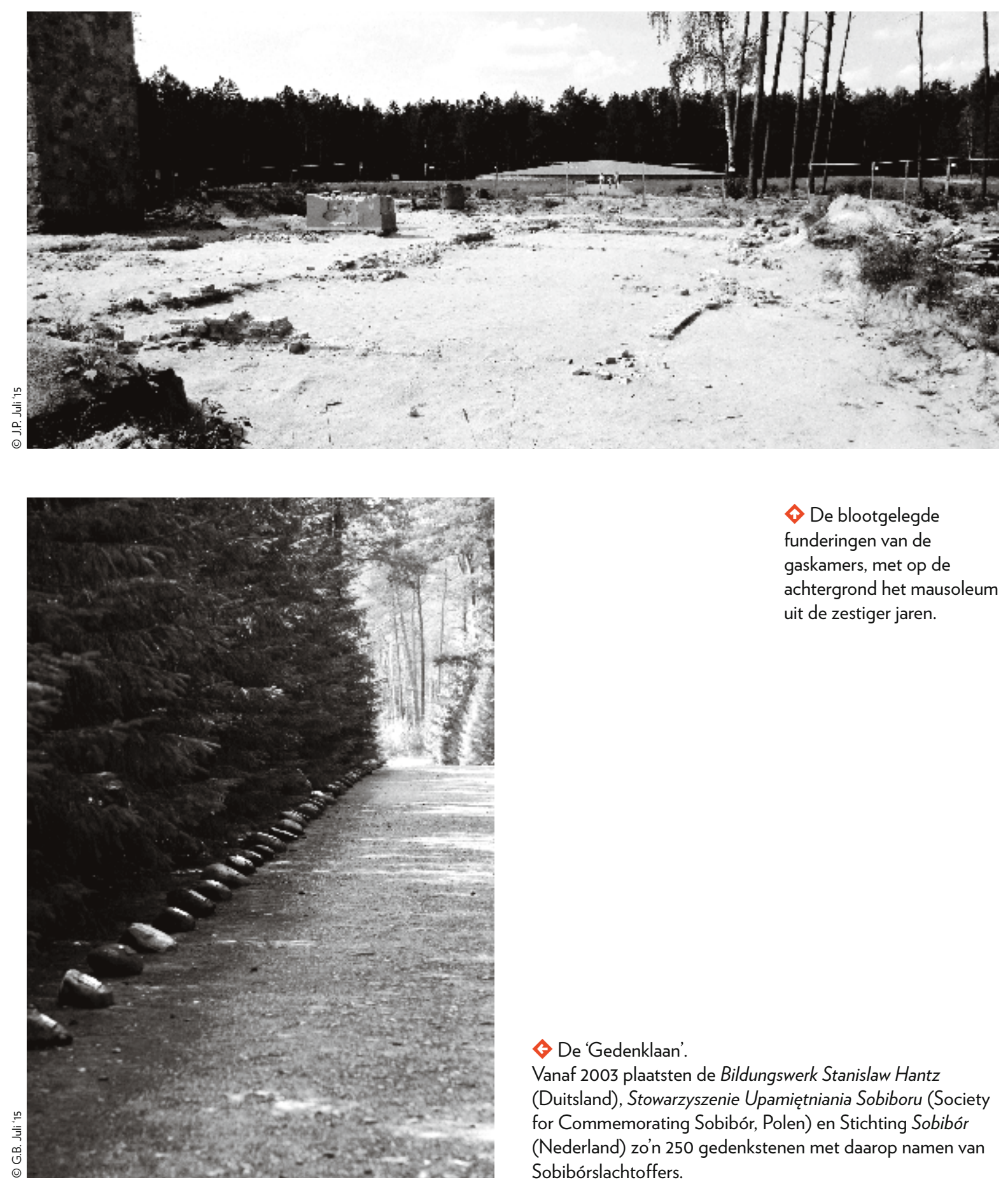

$\uparrow$ De blootgelegde funderingen van de gaskamers, met op de achtergrond het mausoleum uit de zestiger jaren. $\diamond$ De 'Gedenklaan'.

Vanaf 2003 plaatsten de Bildungswerk Stanislaw Hantz (Duitsland), Stowarzyszenie Upamiętniania Sobiboru (Society for Commemorating Sobibór, Polen) en Stichting Sobibór (Nederland) zo'n 250 gedenkstenen met daarop namen van Sobibórslachtoffers. 


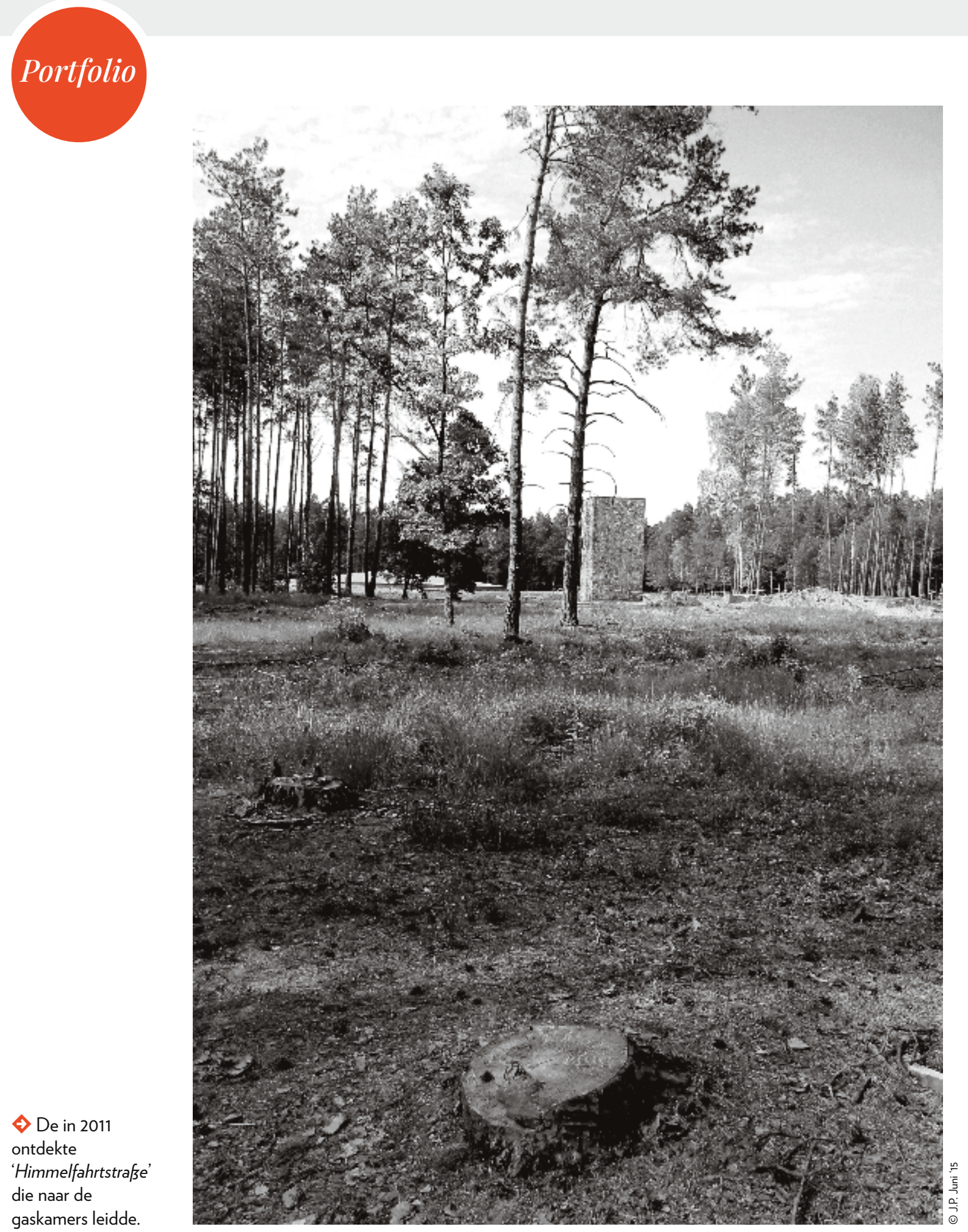




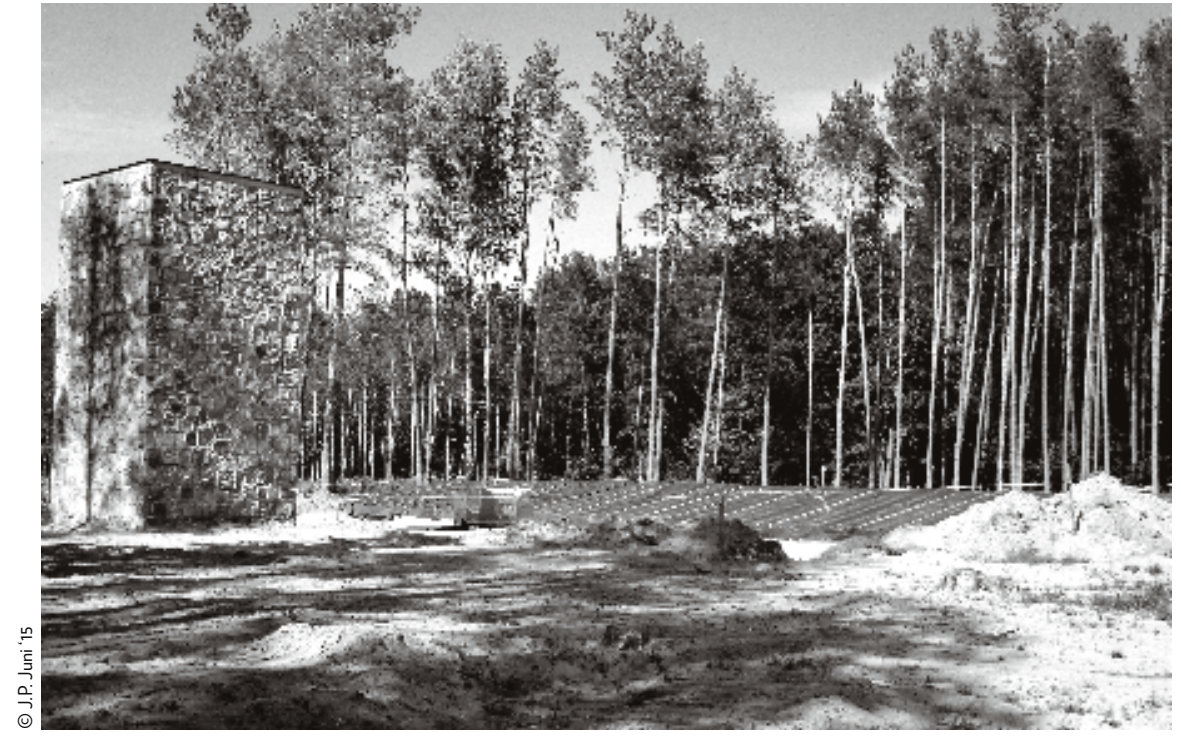

$\leftrightarrow$ Een zicht op de ontdekte funderingen van de gaskamers (hier onder een plastieken doek) vanaf de getraceerde 'Himmelfahrtstrafee'. Dit zal deel uitmaken van het nieuwe memoriaal.

$\checkmark$ In 1965 bouwde de Poolse kunstenaar Mieczysław Welter het mausoleum op de plaats waar lichamen verbrand en in kuilen begraven werden.
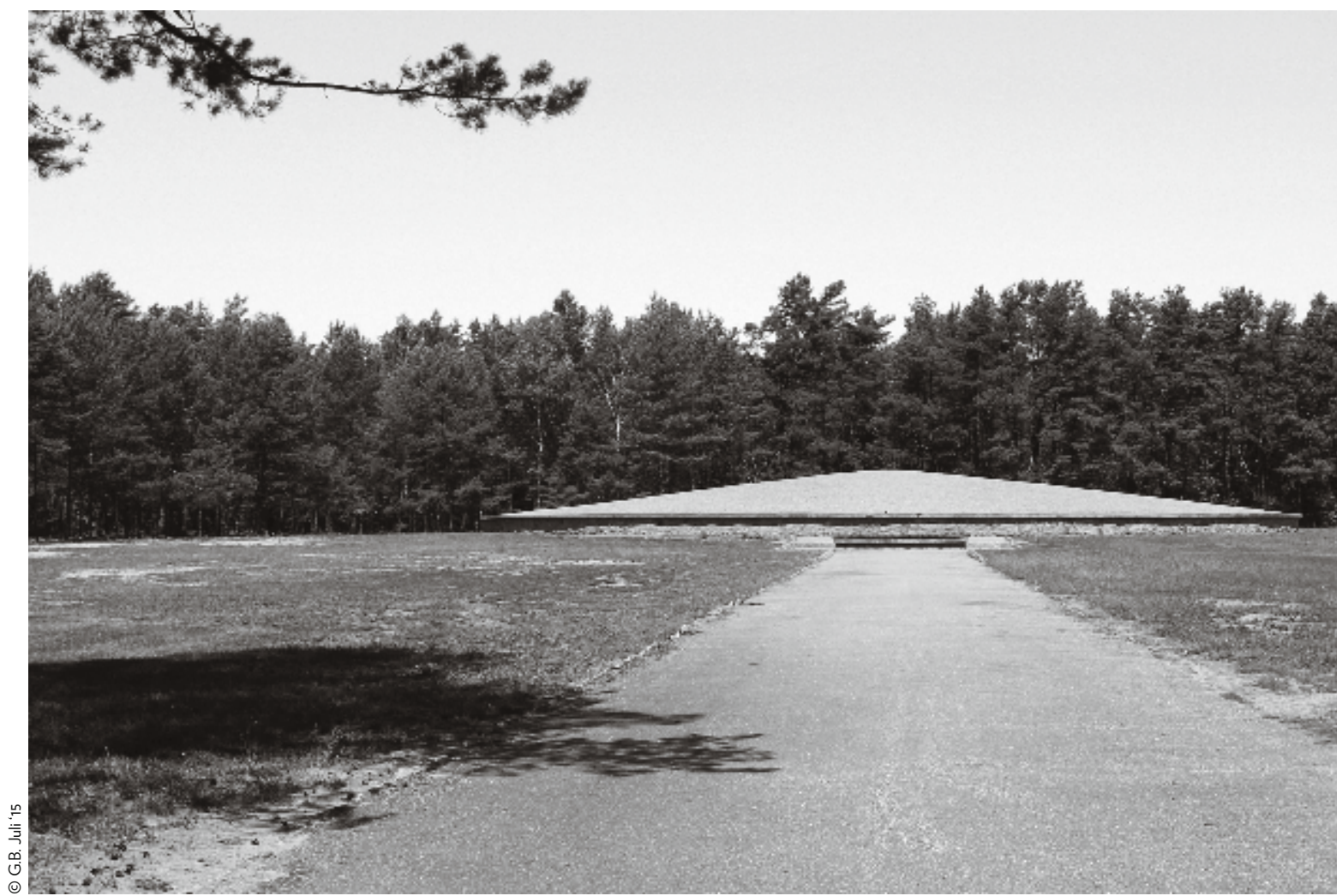